\title{
Disaster Management in Wetland Settlement at Ogan Komering ILIR Regency, South Sumatera
}

\author{
Novrikasari, Desheila Andarini, Mona Lestari, Anita Camelia
}

\begin{abstract}
Ogan Komering Ilir (OKI) Regency is part of the South Sumatra Province whose area is prone to flooding and fire. As for the tropical region, OKI also has two extreme seasons between the rainy and dry seasons. In the dry season is a prone period of forest and land fires, while in the raining season, its prone to flooding. This study aimed to conduct Disaster Management in Wetland Settlements at Ogan Komering Ilir Regency. The method was using qualitative study design with six informant that consist of six local community and two key informant from worker of Badan Penanggulangan Bencana Daerah and Dinas Kesehatan OKI. The result showed that disaster management was classified into four phase. First, the phase of prevention and mitigation that analyzed socialization efforts conducted in OKI were distribution of leaflets and posters. Then, phase of disaster preparedness showed preparedness program in OKI has not been implemented optimally. In disaster emergency response phase discovered no specific procedure in disaster management. Moreover, the phase of disaster recovery indicated that collaborative efforts with multi-sector stakeholders have been conducted. It can be concluded to prepare Disaster Response Village Programs in Ogan Komering Ilir.
\end{abstract}

Index Terms: Disaster Management; Wetland Area; Ogan Komering Ilir Regency

\section{INTRODUCTION}

Indonesia has a beautiful natural formation because the territory of Indonesia is a meeting place between two sets of young mountain ranges in the world, Pacific Circum (the folds that surround the Pacific Ocean) and the Mediterranean Circum (folds of mountains that start fro $\mathrm{m}$ the Atlas mountains in North Africa to Nicobar, as a result Indonesia are areas that prone to natural disasters. Besides that, Indonesia has abundant mineral minerals due to its geological position. The meeting of three large tectonic plates, the Indo-Australian plate, Eurasia and the Pacific plate also caused Indonesia to include the world's Pacific ring of fire or fire pathway, which is an area that often experiences earthquakes and volcanic eruptions that surround the Pacific Ocean basin ${ }^{(1)}$.

Revised Manuscript Received on September 22, 2019.

Novrikasari, Universitas Sriwijaya, Jl. Raya Palembang Prabumulih Km. 32, Indralaya Ogan Ilir, Palembang, Sumatera Selatan, Novrikasari@Fkm.Unsri.Ac.Ida

Desheila Andarini, Universitas Sriwijaya, Jl. Raya Palembang Prabumulih Km. 32, Indralaya Ogan Ilir, Palembang, Sumatera Selatan, Desheila_Andarini@Fkm.Unsri.Ac.Idb

Mona Lestari, Universitas Sriwijaya, Jl. Raya Palembang Prabumulih Km. 32, Indralaya Ogan Ilir, Palembang, Sumatera Selatan

Anita Camelia, Universitas Sriwijaya, Jl. Raya Palembang Prabumulih Km. 32, Indralaya Ogan Ilir, Palembang, Sumatera Selatan
According to data from the Head of Badan Nasional Penanggulangan Bencana and Public Relations Center, Sutopo Purwo Nugroho, stated that there has been an increase in the trend of natural disasters by $350 \%$ in the past three decades ${ }^{(2) .} \quad$ This increase, especially in hydro-meteorological disasters that affected by weather aspects, such as floods, landslides, tornadoes and droughts. This type of disaster $80 \%$ occurs in Indonesia and caused by changes in the environment and regional factors, in the form of global climate change. Disasters have a significant effect on economic development for a nation. The risk of natural disasters has a negative influence on development, especially economy aspect.

South Sumatra is an area of wetland that is quite extensive and has a tropical and wet climate with rainfall of 1,500-3,200mm/year (average per month of $195.8 \mathrm{~mm}$ ). Land cover conditions have a large influence on the potential for fires in an area. The type of land, the extent and type of vegetation are directly correlated with the amount of fuel supply and the level of ease of burning. The amount of sleeping land in South Sumatra which is generally dominated by the types of Imperata and shrubs as well as the activities of encroachment and illegal logging increase the level of risk of forest and land fires. The geomorphological condition is a fairly extensive peat wetland type that dominates the four regencies in South Sumatra, Musi Banyuasin District, Banyuasin, Ogan Ilir and Ogan Komering Ilir. Therefore, it is known that peatlands are flammable when dry and become the main source of smog in the forest and land fire season. Moreover, most of the local resident live permanently in the wetland ${ }^{(3) .}$

Based on the results of preliminary observations, it is known that Ogan Komering Ilir (OKI) Regency is part of the South Sumatra Province whose area is prone to flooding. The sub-districts of Ogan Komering Ilir were subscribed to floods, landslides and tornadoes. As for the tropical region, OKI also has two extreme seasons between the rainy and dry seasons. In the dry season is a prone period of forest and land fires so that the Ogan Komering Ilir is categorized into areas prone to disasters. Therefore, in order to minimize the occurrence of disasters in Ogan Komering Ilir, it is important to conduct research on disaster management models. With this research, it is expected that the community will be able to know what actions need to be taken in the event of a disaster and post-disaster, especially in the disaster-prone of Ogan Komering Ilir Regency. This study supports the achievement of the strategic

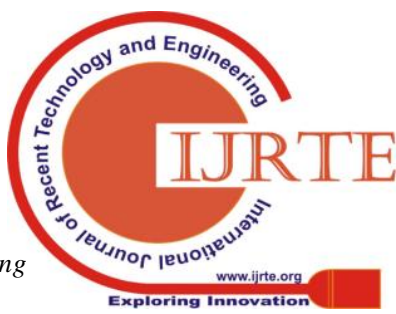


plan and research road map of Sriwijaya University in the field of occupational health and safety by taking the research subject of wetland areas in Ogan Komering Ilir Regency. The target of this research is the establishment of a disaster management model in a wetland residential area in District Ogan Komering Ilir.

\section{LITERATURE REVIEW}

\section{A. Disaster Management}

According to ${ }^{(4)}$, disaster management is knowledge that studies disasters and all aspects related to disasters, especially disaster risk and how to avoid the risk of such disasters. Disaster management is a dynamic process of working planing, organizing, actuating and controlling functions. Every geo-hazard should be identified and evaluated in order to minimize the disater ${ }^{(5)}$. Various parties involved in disaster management must cooperate with each other and provide the same view on disasters through an agreed system or rule, namely the Disaster Management System. In disaster management by the government, especially local governments, if the disaster is regional in scale, according to ${ }^{(6)}$ states that in managing this disaster the government has goals such as:

1. Identify people and regions that are vulnerable to disasters within the district

2. Ensure that all community members are aware of the potential impact of natural

3. disasters

4. Share good practice advice and guidelines for the community for disaster mitigation

5. Maintain relationships with officials responsible for planning, health and welfare by

6. issuing warnings or mass control systems

7. Ensure that community members receive appropriate first aid or first aid training

8. Carry out community education and awareness programs through activities that

9. work with local schools

10. Identify evacuation routes and locations of safe places and locations of refugees

\section{B. Disaster Management Stage}

\section{1) Pre-Disaster}

\section{a) Prevention}

Prevention can be interpreted as measuring and estimating what disasters will occur, in this case it is classified as very difficult to predict. However, at this stage all elements must estimate activities that can reduce the disaster will not occur even worse and can cause greater losses.

\section{b) Mitigation}

Mitigation is a precautionary measure taken so that the disaster risk will have little impact. Undang-undang No. 24 (2007) concerning about Disaster Management said that mitigation can be carried out through various ways including the implementation of spatial planning, development arrangements, infrastructure development, building management, and which are not less important in the provision of good education, extension and training both conventional and modern. In the stages there are various types of mitigation including structural mitigation and nonstructural mitigation.

\section{c) Preparedness}

Preparedness is an alert state in the face of crises, disasters or other emergencies. Emphasizing preparedness as an action taken before an emergency to develop operational capabilities and to facilitate an effective response if an emergency occurs ${ }^{(7)}$. Preparedness is more related to activities and steps taken before a disaster occurs ${ }^{(8)}$. The purpose of preparedness is to anticipate the problems and resources needed to respond effectively before the disaster occurs. The term between mitigation and preparedness has the same characteristics, but both terms have differences, according to ${ }^{(9)}$ the difference between mitigation and preparedness is that mitigation considers disasters to be prevente $\mathrm{d}$ or the impact can be reduced, but preparedness assumes that disasters will happens and the community must be prepared to face it.

Preparedness as in Undang-undang No. 24 (2007) are carried out through:

1. Preparation and testing of disaster emergency response plans,

2. Organizing, installing and testing an early warning system

3. Provision and preparation of supply goods to fulfill basic needs

4. Organizing, counseling, training and rehearsing on emergency response

5. mechanisms

6. Organizing, counseling, training and rehearsing on emergency response

7. mechanisms

8. Compilation and accurate, information and updating of disaster emergency response

9. procedures, and

10. Provision and preparation of materials, goods and equipment to fulfill the recovery of infrastructure and facilities.

\section{2) During a Disaster}

Disaster emergency response is a condition determined by the government for a certain period of time on the basis of recommendations from the institution that is given the task of overcoming disasters starting from emergency alert status, emergency response and emergency transition to recovery. Disaster emergency preparedness is a condition that has the potential for natural disasters which is an increase in threats, the determination of which is based on the results of accurate monitoring by the competent agency and takes into account the real conditions or impacts that have been caused to the community. In determining the status of disaster

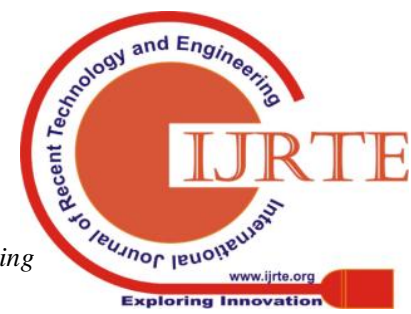


emergency, it is carried out by the central government and the regional government at the suggestion of the head of Badan Nasional Penanggulangan Bencana or Badan Penanggulangan Bencana Daerah.

An emergency transition to recovery is a situation where the handling of emergencies is temporary and permanent with the aim that vital facilities and infrastructure as well as the socio-economic activities of the community will immediately function again. This emergency response will be carried out until the rehabilitation and reconstruction phase begins.

\section{3) Post-Disaster}

Post-disaster, often referred to as recovery, is the activity of returning the infrastructure system to minimum operating standards and guidance on long-term efforts designed to restore life to normal conditions and conditions or to better conditions after a disaster.

According to Undang-undang No. 24 (2007) states that recovery is a series of activities to restore the condition of the community and the environment affected by the disaster by re-functioning of institutions, infrastructure and facilities by carrying out rehabilitation efforts. The improvement process is prioritized on the basic needs of the affected communities, such as housing, sanitation facilities, the needs of affected communities, and then continued with the improvement of infrastructure that supports the recovery of the economic sector in the affected areas. In post-disaster, it is known as rehabilitation and reconstruction, where rehabilitation is an improvement and restoration of all aspects of public or community services to an adequate level in post-disaster areas with the main goal of normalization or proper operation of all overnment specs and people's lives in post-disaster areas.

Reconstruction is the rebuilding of all institutional facilities and infrastructure in post-disaster areas, both at the government and community levels with the main goal of growing and developing economic, social and cultural activities, upholding law and order, and the rise of community participation in all aspects of community life in the post disaster.

\section{METHODOLOGY/MATERIALS}

This research was carried out on wetland settlements in Ogan Komering Ilir Regency and was an observational study with qualitative approach. The results of the observation are made a check list, then analyzed using disaster management guidelines. The sources of information in this study were key informants and informants. Determination of this information source is done by purposive sampling (Moleong, 2010). In this study the key informants were BNPB Officer of Ogan Komering Ilir and Ogan Komering Ilir Health Office. The informants consisted of ten community members in Ogan Komering Ilir. In this study primary data collection was conducted by interview using interview guidelines and direct observation. Secondary data in this study are research place profiles and other supporting documents. The instruments of data collection used in this study are in-depth interview guidelines that contain questions to gather information according to the objectives of the researcher, checklist of observation sheets, cameras and stationery. The data processing process uses a computer with the Microsoft Word program. The process of data analysis is carried out using international and national guidelines and regulations as well as theories and results of previous research related to Disaster Management.

\section{RESULTS AND FINDINGS}

\section{A. Disaster Prevention and Mitigation Phase}

Based on the results of in-depth interviews with key informants it is known that in the phase of disaster prevention and mitigation in Ogan Komering Ilir District already had efforts to prevent disasters in the form of warning boards but socialization to surrounding communities was still rarely done, only they had routine patrol programs. This can be seen from the results of the following interview:

"warning boards that are installed in disaster-prone areas or those that are rare ... socialization invites people from the village head, from the sub-district, if our disaster is said the program should have a disaster prevention and mitigation program in the field. but the implementation of the activities such as socialization and installation of warning boards and disaster response villages. Now that's it. then the program handled by the other was an emergency and logistical preparedness improvement program, and then the BRR had a rehabilitation and reconstruction program. the funds are almost $100 \%$ from the center. That's what was done. Now specifically related to forestry, it is not yet available for 2018 but after the change there was a question of recruitment of the bureaucracy, part of the activity was also included in the assessment of the posts during emergency alert yesterday, right. same with the warning board too..." (TS)

"For us, this is through the patrol activities of both bath and integrated patrols. In this implementation, there are many activities that carried out there, that means when the patrol is carried out with rain conditions or the fuel conditions are quite safe. The patrol team will socialize these regulation to the community, about rules, prohibition of burning and also sanctions etc. It can be socialized through patrol activities, both independent and integrated patrols. Then we also had a socialization activity and campaign activities in schools. There was also a possibility that the government regulation would be related to the impact hazards of karhutla and other regulations that had regulations that were socialized in campaign activities, counseling and socialization and patrolling. also able to carry out socialization activities as well, not only walking just seeing but because they were there at the location until months they did not go home they lived in the area then told the community..." (TI)

Based on the results of in-depth interviews with informants it is known that in the phase of disaster prevention and mitigation are as follows: 
"Like a poster, or write the deck. It is written as this penalty is right. When burning the forest ... this is a punishment ... (R)

"Maybe this was what made the billboards in the sub-district office which was important about not burning the forest. If it's not mistaken, from the government, , especially from the Regent, directly conveyed about the fire excerpts, when he delivered a speech during Eid Al-Fitr, he usually said that the dry season is therefore for residents around the city, it is hoped that if this land is used up, it will not be cleaned by burning it like this. It is to prevent it from occurring when there is a smog disaster such as some time ago activities were carried out during a disaster the most reacting is that the community members around us used to be reported to the government first, then the government took that action ... "(L)

"Such as the pamflet of regulation that should be taken such as prohibited from burning the forest.." (YS)

"The prevention is taken from the sticker and pamflet about fire, waste and..." (ES)

\section{B. Disaster Preparedness Phase}

Based on the results of in-depth interviews with key informants it is known that in the disaster preparedness phase in Ogan Komering Ilir Regency already has a program but has not been carried out optimally. This can be seen from the results of the following interview:

"So, it seems like the focus has been lately until it was responded to. Once there is fire, put it out. Already done. That's about the deck. Real simple. But that was once when people talked about asking for risk reduction where the implementation of the program should be done where. well that's heavy. Sometimes we have make a program that never be conducted. We also don't really expect it, but what we arrange like a contingency plan should be able to handle it. So, we hope that this disaster will not happen actually. As long as you hope that it doesn't happen, do the efforts that when that disaster happens we have been ready ... "(TS)

... "In 2018 it has not reached the level of community evacuates, even there have been fires but handling has been faster so that it does not cause smog. The biggest fear is not forest fires but smog. So in 2018, thank God, it did not take up the sacrifice, both the victims of material and spiritual... "(TI)

Based on the results of in-depth interviews with informants, it is known that the disaster handling phase is as follows:

"yes that one. When the fire comes, we usually call the fireman from Kayuagung. What make me afraid is from the electricity at home. But, fortunately, fireman can handle the fire ... it was immediately given from the fire department who immediately turned off the electricity ... "(R)

"I do not know, but usually not from the BPBD who come for disaster situation. It from BNPB that immediately carries an address by using helicopter carrying water to water the land directly to the burning area..." (L)

..." When we give the news, for example, there is a fire here, right away, or they come directly, they are sprayed using water, right ... "(YS)

"There was a forest fire yesterday in Muara Batun area ... there was also a frequent flood ... in that area ... because the river mouth was too unprocessed. recently also what incident was intentional or did not know clearly that there was land on the river side opposite the toll road, the toll road that had just been built, now it was a fairly extensive land fire incident. Recently only 2 months or 3 months ago ... "(ES)

\section{Disaster Emergency Response Phase}

Based on the results of in-depth interviews with key informants, it was found that in the disaster emergency response phase in Ogan Komering Ilir District the disaster management phase had not been maximized. This can be seen from the results of the following interview:

"in the disaster emergency response phase has not work optimal. If there is a disaster, all of the community from the government, private sector, one where the spot position was the fire.We go right there ... "(TS)

"So our mechanism will refer to the emergency response given by the governor. Manggala is a group under the supervision of the Ministry of Environment and Forestry. Then the Ministry of Environment and Forestry responds to the emergency response which has integrated the patrol activities involving the Indonesian National Police and the community. There are elements of the TNI, National Police and elements of the community. For South Sumatra there are 50 posts, and there are 13 posts. The vulnerable sub-district posts in OKI, their posts are on location. This is also our synergistic form with the Indonesian National Armed Forces and the community. We jointly carry out prevention efforts in the field through integrated patrols initiated by the Ministry of Environment and the forest, meaning all budgets covered by Ministry of Environment \& Forestry ... "(TI)

Based on the results of in-depth interviews with informants it is known that in the disaster emergency response phase are as follows:

"Yesterday the burning house was given funding by the governor...." (R)

"The handler is BNPB intervenes directly to the village to water it, he left the fire point in the OKI area. Maybe the flow of the process is actually exists but does not not appear in the public so that the public is somewhat lacking. Until they can only see what can be seen and there are helicopters carrying the water. The government need to assigns rescue group to go down to the village to socialize about negative impact as a result of burning the land and regulations, and the most important thing is how to respond If a disaster occurs or the first land fire .. (L)

"for emergency response there are usually karang taruna. It's no longer active ... "(YS)

" there is a shoulder who are willing to watch over the cause of the fire. For floods, it is because of the annual flooding, if for example it is often jugo two days a day, so it is not too many months or not weeks. if in terms of forest fires, surely that anticipation will extinguish the fire. Whether it's in the form of a traditional

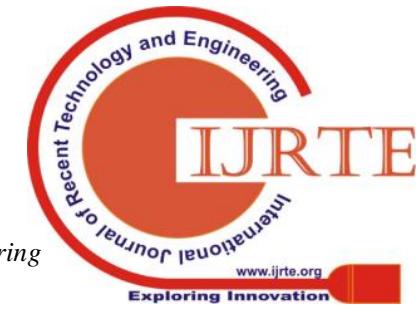


tool or from the help of a fire extinguisher. That must be there. Yeah ... helicopters often go around. Bring it like a big tank. It must be around; ... "(ES)

\section{Disaster Recovery Phase}

Based on the results of in-depth interviews with key informants, it is known that in the phase of disaster recovery in Ogan Komering Ilir District, it already has collaborative efforts with multi-sector stakeholders. This can be seen from the results of the following interview:

"After disaster, we focus on cooperation with Dinas Pekerjaan Umum. Usually, if the flood occurs, the damaged roads need revitalization. We propose to the center office to make improvements. The essence of the ecosystem must be restored. If the fire is come from the company, and it is proven. Because this fuel is included in the criminal domain there is also a criminal offense. for example, it burned it. so that of course our steps in that case are good, not to let the stakeholders disturb the community. If this land is burned, please plant it again. What is clear is that the ecosystem must be maintained, the environment must not be damaged right. even if it has happened like that, it is trying to repair reforestation, but not here too. There are technical agencies such as forestry, environmental management. We don't know anymore from BPBD. Then from the increase in understanding before before it actually happened, namely socialization, then appeals in the form of electronic correspondence ... "(TS)

"The disaster recovery program consisted of community awareness program, socialization, coaching and medical treatment...." (TI)

Based on the results of in-depth interviews with informants it is known that the disaster recovery phase is as follows:

"because this disaster was only recently this year, the term is excited. But 1 have no idea about disaster recovery program in this village ... "(R)

"I don't know maybe there is a socialization about this from the government or from the news, because we in the village rarely open mass media like, maybe the newspaper exists.... "(L)

"if you prevent the occurrence of a disaster, maybe from the counseling there are words oh no. if the fire is often certain, it must be talked about. You don't leave the cigarette cutter or don't burn your land without permission from certain service agencies. ... "(ES)

\section{DISCUSSION}

Indonesia is located in a disaster-prone area with various types of natural disasters that occur both on a light and medium scale which have a negative impact on the lives of its people. This has caused Indonesia to be vulnerable to disasters not only in terms of physical / natural factors but also socio-economic factors. Based on disaster-prone index data issued by the National Disaster Management Agency in 2010 from a total of 386 districts in Indonesia a total of 175 regencies were included in the category of high disaster prone, 179 districts were medium category of disaster prone, and 32 regencies fall into the category of low disaster prone. The level of vulnerability becomes actual according to the International Strategy for Reduction 2006-2009 of UNESCO World Disaster Reduction Campaign in 2005. Natural disasters that occurred in Indonesia get 7 th ranked in the world for the level of damage and losses caused. As for the South Sumatra region, Ogan Komering Ilir Regency, especially in Jejawi District, is an area that often experiences disasters in the form of forest and land fires and floods.

The following are the results of the discussion of each phase of disaster management:

\section{1) Disaster Prevention and Mitigation Phase}

Based on the results of the study, it was found that the disaster prevention and mitigation phase in Ogan Komering Ilir District already had efforts to prevent disasters in the form of warning boards but socialization to the surrounding community was still rarely done, except that they already had a routine patrol program. This is in line with the research stated that settlements on the banks of the Code River are quite dense, irregular and located very close to the river border line so that at any time a flood can pose a big risk especially for slum and semi-permanent homes (10). Structural and non-structural disaster mitigation is needed to reduce the risk of flooding. Structural mitigation is carried out by making embankments, strengthening building structures to make water absorption, building houses with high foundation or making stilt houses. Non-structural mitigation in the form of public awareness to maintain and maintain the environment in which they live, willingness to be relocated, guarding green areas in water catchment areas by not cutting trees carelessly, dredging sedimentation together, not disposing of garbage into the Code River, utilizing local wisdom (kenthongan) as a warning sign. The research only examines disaster mitigation needed to reduce flood risk both structural mitigation and non-structural mitigation. Other things related to early preparedness and warning have not been described in detail even though in the face of disaster preparedness, early warning and disaster mitigation are three important aspects. Furthermore, in the potential condition of a flood disaster, early preparedness and warning are a priority that must be carried out by various parties in an effort to minimize the risk of disasters, especially the loss of lives.

\section{2) Phase of Disaster Preparedness}

In reality, there are still many different interpretations of the concept of preparedness in society. In the study of the development of a community preparedness assessment framework, a concept from Nick Carter has been used regarding preparedness from a government, a community group or individual, namely actions that allow governments, organizations, communities, communities and individuals to be able to respond to a disaster situation quickly and effectively ${ }^{(11)}$. Included in preparedness actions are disaster management planning, resource maintenance and personnel training ${ }^{(12)}$

Based on the results of the study that the disaster preparedness phase in Ogan 
Komering Ilir. District already had a program but it had not been implemented optimally. Disaster preparedness is needed with the aim that the community is encouraged, the emergence of attention and concern for disaster management efforts in particular landslides and is involved and can actively participate in implementing a series of landslide risk reduction activities in the region $\left({ }^{13}\right)$. Community involvement not only includes internal involvement in the community, but also the involvement of the external environment of the community. The involvement of all components of society creates a synergy of cooperation and coordination that leads to changes.

Efforts to engage here are linked to community participation in disaster management efforts, where the involvement of mass community actively in disaster preparedness activities is very important to achieve mitigation efforts disaster. The processes of preparedness activities are a strategy to improve the capacity of the community, so that the community can learn in organizing and developing all the potential they have to meet the needs of disaster management.

\section{3) Disaster Emergency Response Phase}

Based on the results of in-depth interviews with key informants, it was found that in the disaster emergency response phase in Ogan Komering Ilir District, the disaster management phase had not been maximized. Article 33 of the Disaster Management Law states that the implementation of disaster management consists of 3 (three) stages including, a. Pra disaster; b. During emergency response; and c. post-disaster. Furthermore Article 48 of the Disaster Management Law states that the implementation of disaster management during emergency response includes: a. rapid and accurate assessment of location, damage and resources; b. determining the status of a disaster emergency; c. rescue and evacuate affected communities; d. fulfillment of basic needs.

Based on Law Number 24 of 2007 concerning Disaster Management, the main agency specifically dealing with disaster management at the national level is the National Disaster Management Agency (BNPB). BNPB is a non-Ministry Government Institution led by ministerial level officials. This institution has the duty to formulate and determine disaster management and refugee handling policies by acting quickly and accurately, effectively and efficiently, and coordinating the implementation of planned, integrated and comprehensive disaster management activities. In the implementation of disaster emergency response BNPB does not work alone but cooperates with the Ministry of Finance, related institutions and agencies. For the search and rescue of disaster victims, BNPB cooperates with the Indonesian National Army, National Police of the Republic of Indonesia, National Basarnas, and PMI. For handling refugees, BNPB cooperates with the Ministry of Social Affairs

\section{4) Phase of Disaster Recovery}

Based on the results of the study, it was found that in the phase of disaster recovery in Ogan Komering Ilir Regency, there had already been collaborative efforts with multi-sector stakeholders. The success of disaster risk management is inseparable from the role of various parties such as volunteers, the community, non-governmental organizations (NGOs) or non-governmental organizations (NGOs), government and even the international community. Collaboration between these various parties will accelerate tackling various disaster issues and minimize the impact of the risks caused by disasters quickly and effectively, both short and long term in the affected areas ${ }^{(14)}$.

Birth of Law No. 24 of 2007 concerning Disaster Management and implementing regulations that have been prepared, it is expected that the response to the disaster situation will be faster so that disaster risk management becomes more effective. Effective disaster risk management requires a combination of four concepts, including all hazards, comprehensive, integrated and community preparedness. An integrated approach to effective disaster management requires active collaboration from various stakeholders. That is, all organizations with their respective duties cooperate in managing disasters. Communities consisting of each individual are expected to always be alert to disaster hazards and know how to protect themselves, their families and their property from disaster hazards. If each can take protective measures against the effects of disaster hazards, it can certainly reduce the threat of disaster hazards. Things that need to be considered are the focus of response to preparedness, migitation, response and recovery activities can be done well, so that the impact of disaster events will be more minimized.

\section{CONCLUSION}

1. In the disaster prevention and mitigation phase of wetland settlements in Ogan Komering

Ilir District, there have been socialization efforts in the distribution of leaflets and posters.

2. In the phase of disaster preparedness in wetland settlements in Ogan Komering Ilir

Regency already has a preparedness program but has not been implemented optimally.

3. In the disaster emergency response phase in wetland settlements in Ogan Komering Ilir

District, it is known that the disaster management stage has not been maximized.

4. In the phase of disaster recovery in wetland settlements in Ogan Komering Ilir Regency they already have collaborative efforts with multi-sector stakeholders.

\section{ACKNOWLEDGEMENTS}

This research work is supported by Lembaga Penelitian dan Pengabdian Masyarakat Universitas Sriwijaya.

\section{REFERENCES}

[1] Warto, Agus T, Sunit. \& Nugroho P W. Management of Disaster Victims in Communities in Natural
Disaster-Prone Areas in the Era of
Regional Autonomy.
Yogyakarta; 2002.
Published By:
Blue Eyes Intelligence Engineering
\& Sciences Publication 
[2] BNPB. Disaster Management. J Disaster Manag. 2011;02.

[3] Anwar WFF, Nugroho S. The control of wetland development with community preference in changing home design. J Perspekt Arsit. 2015;10(1):56-68.

[4] Nurjanah et al. Disaster Management. Jakarta: Alfabeta; 2011.

[5] Hidayah K. DI ERA OTONOMI DAERAH ( Kajian Terhadap Penanganan Kasus Luapan Lumpur Lapindo Brantas ) 1 DISASTER MANAGEMENT POLICIES ( Study on Handling Cases Surge Lumpur Lapindo Brantas ). Borneo Adm. 2015;11(3):298-315.

[6] Solway. Reducing the Effect of natural Hazards on Urban Areas. Nat disasters Sustain Dev. 2004;(In R. Casale \& C. Margottini (Eds.)).

[7] Godschalk. Disaster Mitigation and Hazard Management. In: In Darbek Springfield; 1991. p. 199-212.

[8] Mercer, Pearson S, I Kelman, L Teranis J. Framework for integrating indigenous and scientific knowledge for disaster risk reduction. Disaster. 2010;34(1):214-39.

[9] Myers A, McEntire DA. Preparing communities for disasters: issues an processes for government readiness. Disaster Prev Manag An Int J [Internet]. 2004 Apr 1;13(2):140-52. Available from: https://doi.org/10.1108/09653560410534289

[10] Wahida. Flood Disaster Mitigation in the Code City Riverbank Yogyakarta. Universitas Gadjah Mada; 2009.

[11] GFDRR. Integrating Disaster Risk Reduction into Poverty Reduction, Annual Report, Global Fund for Disaster Reduction and Recovery [Internet]. Washington Dc; 2009. Available from: http://www.gfdrr.org/gfdrr/sites/gfdrr.org/files/publication/GFDRR_An nual_Report_2009.pdf.

[12] Hidayati D. Community Preparedness Study in Anticipating Earthquake \& Tsunami Disasters. LIPI. Jakarta; 2006.

[13] Muis, Ichwan AK. Community Preparedness Model in Landslide Disaster Risk Reduction in Tugumukti Village, Cisarua Subdistrict, West Bandung District, Indonesia. Asian Soc Work J. 2018;3(4):19-30.

[14] Paidi. RISK MANAGEMENT OF NATURAL DISASTERS IN INDONESIA. Manag J. 2012;29:321.

\section{Authors Profile.}

I am Novrikasari from Universitas Sriwijaya, Jl. Raya Palembang Prabumulih Km. 32, Indralaya Ogan Ilir, Palembang, Sumatera Selatan. My area of interest is sustainability.

I am Desheila Andarini affiliated from the Universitas Sriwijaya, Jl. Raya Palembang Prabumulih Km. 32, Indralaya Ogan Ilir, Palembang, Sumatera Selatan. My area of interest is disaster management.

My name is Mona Lestari affiliated from the Universitas Sriwijaya, Jl. Raya Palembang Prabumulih Km. 32, Indralaya Ogan Ilir, Palembang, Sumatera Selatan. My area of interest is disaster management.

I am Anita Camelia from Universitas Sriwijaya, Jl. Raya Palembang Prabumulih Km. 32, Indralaya Ogan Ilir, Palembang, Sumatera Selatan. My area of interest is disaster management. 